\title{
33 \\ AMERICA'S DRONE WARS OUTSIDE OF CONVENTIONAL WAR ZONES
}

\author{
Peter Bergen and A.G. Sims ${ }^{1}$
}

On March 5, 2016, a large group of men gathered for a graduation ceremony in Raso, Somalia, a remote area 190 kilometers north of the capital, Mogadishu. U.S. intelligence assets had quietly observed for weeks as dozens of al-Shabaab militants trained for a large-scale attack against American troops in East Africa. ${ }^{2}$ In a bombardment of drone strikes and airstrikes, the United States decimated the al-Shabaab training camp, killing more than 150 militants. $^{3}$ The March 2016 strikes in Somalia were the most lethal attacks using drones outside of a traditional war zone.

In October 2001, the first armed drone strike in Afghanistan targeted Taliban leader Mullah Muhammad Omar. The strike was unsuccessful. ${ }^{4}$ After the failed attempt, drones emerged as a key U.S. counterterrorism tool. As of December 1, 2020, the United States has conducted 414 drone strikes in Pakistan, 374 counterterrorism operations in Yemen, and 253 operations in Somalia that include a mix of drone strikes, airstrikes, and ground raids, according to data from the New America think-tank. ${ }^{5}$

This chapter explains how armed drones targeting suspected terrorists outside of traditional war zones are changing the character of warfare while at the same time raising questions about the legality of drone strikes conducted far from recognized battlefields. It reviews how three different American presidents relied on armed drones to strike at hard-to-reach targets.

\section{The formation of the U.S. drone program}

The remotely piloted aircraft's novelty is its ability to stay aloft over locations for extended periods to gather real-time intelligence while also being able to act on this information immediately using precision munitions. Drone warfare is also taking place in an unprecedented information environment in which the U.S. government collects ever-vaster amounts of data.

Drones represent just one aspect of America's comprehensive international surveillance infrastructure. This data collection is so extensive that the National Security Agency can reportedly record every phone call that is made in a particular country. ${ }^{6}$ It is this merger of "big data" and drone technology, complemented by human intelligence about suspected terrorists, that has made drone warfare against al-Qaida and other jihadis so effective. ${ }^{7}$

Not long ago, killing a terrorist on the other side of the world with an armed drone would have been in the realm of science fiction. Before the 9/11 attacks, the United States had only a handful of experimental drones, and they had never been used to kill anyone. By 2012, however, the United States had some 7,500 
drones in its arsenal, more than 100 of which are armed drones that have killed thousands of suspected militants outside of traditional war zones. ${ }^{8}$

Over the course of the war on terrorism, the United States has used the drone program to extend its pursuit of al-Qaida and its affiliates, the Islamic State, and the Taliban beyond the conventional battlefields of Afghanistan, Iraq, and Syria to Pakistan, Somalia, and Yemen. The United States has also conducted air campaigns in Libya that included airstrikes and drone strikes. ${ }^{9}$

The United States is not in a formal state of hostilities in countries such as Libya, Pakistan, Somalia, and Yemen, but the post-9/11 Authorization for the Use of Military Force, which Congress passed just days after al-Qaida's attacks on the World Trade Center and Pentagon, authorized President George W. Bush to "use all necessary and appropriate force against those nations, organizations, or persons he determines planned, authorized, committed, or aided the terrorist attacks that occurred on September 11, 2001, or harbored such organizations or persons." ${ }^{10}$

Two presidents later, this is the same authorization that has been broadly interpreted to allow lethal military actions, including drone strikes, against groups such as the Islamic State, al-Qaida in the Arabian Peninsula (AQAP), al-Shabaab, and the Pakistani Taliban. Few of these strikes have any direct connections to the perpetrators of the $9 / 11$ attacks, but the Authorization for the Use of Military Force remains the critical piece of legislation approving lethal drone operations.

President Bill Clinton's counterterrorism coordinator, Richard Clarke, saw the promise of drones earlier than most. On a drone feed in 2000, Clarke saw a fuzzy glimpse of what might have been Usama bin Ladin in Afghanistan; Predator drone video feeds were not what they are now. Clarke was determined that the next time the United States had al-Qaida's leader, who masterminded the U.S. Embassy bombings in East Africa in 1998, in its sights, American drones would have the capability to kill him and the country's other enemies. ${ }^{11}$

The nascent technology's lack of sophistication was not the only barrier to arming drones. Legal and bureaucratic challenges existed as well. The Air Force did not want to strike Bin Ladin because the United States was not officially at war in Afghanistan or with al-Qaida. ${ }^{12}$ Questions about the Central Intelligence Agency's (CIA) covert action policies contributed to the reluctance of its leaders to arm drones for the purpose of targeted killing.

The original mandate for covert action, codified by President Harry Truman, was explicitly directed toward the communist threat. ${ }^{13}$ Even as the Bill Clinton administration authorized production of drones and tested this new intelligence tool in the Balkans, tensions persisted between the Air Force and the CIA about who should be responsible for the armed drone program. ${ }^{14}$

\section{Drone warfare under President George W. Bush}

In Nevada in June 2001, the CIA built a replica of Bin Ladin's four-room villa at Tarnak Farms, where he was living outside of Kandahar in southern Afghanistan. A Predator drone equipped with a missile obliterated the replica house in tests that the agency conducted with the Air Force.

National Security Council official Roger Cressey recalled that even this was not enough to convince the CIA and Pentagon to move forward with the armed Predator. "I was at the meeting at the agency afterwards," Cressey explained. "The data they got they said was inconclusive as to whether or not there was enough lethality in the explosion or the shrapnel to ensure that everybody inside would have been killed." ${ }^{15}$

Michael A. Sheehan, then the U.S. ambassador for counterterrorism, recalled that Richard Clarke "was pounding on the [CIA and Department of Defense] to more quickly develop—and use - the armed Predator, which was being tested, in Nevada, at the time." According to Sheehan,

both of them were dragging their feet in terms of money, and they also were uncomfortable with the use of the armed Predator. Can you imagine that now? Back then they were very slow 
to develop the capability, very slow in testing, they had lawyers wrapping them up in knots, and Clarke was apoplectic over it, because he wanted to introduce this asset into the Afghan theater. ${ }^{16}$

Even the 9/11 attacks did not end this bureaucratic infighting. On October 7, 2001, on the night of the beginning of the U.S.-led invasion of Afghanistan, a CIA-operated armed drone fired at the Taliban's leader, Mullah Omar, but missed, angering Air Force Lieutenant General Chuck Wald, who was coordinating military airstrikes in Afghanistan and had no prior knowledge of the strike. ${ }^{17}$

On November 13, Kabul fell to the anti-Taliban Northern Alliance. ${ }^{18}$ A few days later, a U.S. drone tracked top al-Qaida commander Mohammed Atef to a house in Kabul, where he was killed in an airstrike. Atef was al-Qaida's military commander and Bin Ladin's chief executive officer, working around the clock to manage al-Qaida's personnel and operations. A Saudi member of al-Qaida recalled that Atef's death "shocked us deeply, because this was the candidate to succeed Bin Ladin."19

After the Taliban were swept from power in Afghanistan, the CIA's secret drone war expanded to other countries. Marine Corps Lieutenant General Michael DeLong, the deputy commander of U.S. Central Command, recalled, "[CIA Director] George Tenet calls me one morning and said, 'We've got our target."' The target was Qaed Salim Sinan al-Harithi. The location was Yemen. Al-Harithi, who was killed by a Predator drone firing a Hellfire missile on November 3, 2002, was believed to have devised the 2000 attack on the USS Cole in Yemen that killed 17 American sailors. ${ }^{20}$

Two years later, the CIA's secret drone program expanded to Pakistan. On June 18, 2004, a CIA drone killed Nek Muhammad, a prominent Taliban leader, as the result of a secret negotiation between Pakistan's intelligence service and the CIA. ${ }^{21}$ The relatively slow pace of drone attacks quickened dramatically in the waning months of the Bush administration's second term after it had become clear that al-Qaida was reconstituting itself in Pakistan's tribal regions.

In July 2007, the 16 agencies that made up the U.S. intelligence community released a National Intelligence Estimate assessing that al-Qaida was resurging and warning that it "has protected or regenerated key elements of its Homeland attack capability, including a safe haven in Pakistan's Federally Administered Tribal Areas (FATA)." What particularly alarmed Bush administration officials was the mounting evidence that al-Qaida and affiliated groups were using the FATA to train Westerners for attacks on American and European targets. For example, the masterminds of the July 7, 2005, London bombings, which killed 52 people, had trained in Pakistan's tribal regions. ${ }^{22}$

In the face of the intense Pakistani opposition to American boots on the ground, the Bush administration chose to rely on drones to target suspected militants. Bush ordered the CIA to expand its drone attacks. A squadron of pilots stationed in Nevada operated the Predator and Reaper drones, which were equipped to drop Hellfire missiles and Joint Direct Attack Munition bombs (utilizing a control system that converts a "dumb bomb" into a guided munition), respectively. More than two dozen feet in length, the drones lingered over the tribal areas, gathering countless hours of video intelligence while seeking targets. ${ }^{23}$

In 2008, the Bush administration dramatically escalated the program, conducting 36 strikes in the president's final year in office- around nine times the highest number of strikes in any previous year. ${ }^{24}$ Overall, Bush authorized a total of 48 drone strikes in Pakistan during his two terms. According to Pakistani and U.S. officials and media reports, drone strikes in 2008 killed about a dozen senior or mid-level leaders from al-Qaida and the Taliban. They included top al-Qaida operative Abu Layth al-Libi, who had orchestrated a 2007 suicide attack at Bagram Air Base in Afghanistan during a visit by Vice President Dick Cheney. ${ }^{25}$

\section{Drone warfare under President Barack Obama}

As soon as he took office in January 2009, President Barack Obama quickly made drones one of his key national security tools. ${ }^{26}$ During the Bush administration, there was an American drone attack in Pakistan every 61 days. During the first two years of the Obama administration, there was a drone strike in Pakistan 
every four days. ${ }^{27}$ By the time he left office, Obama had authorized 353 drone strikes in Pakistan, seven times as many as were carried out during Bush's entire eight years in office. ${ }^{28}$

Under Obama, the targeted killing of al-Qaida leaders also evolved into a broader targeting of lowerlevel members of militant groups. The victims of drone strikes in Pakistan during the Obama era were mostly lower-ranking members of the targeted groups. Under Bush, about a third of all drone strikes in Pakistan killed a militant leader, compared to $14 \%$ under Obama. ${ }^{29}$

Drone attacks called "signature strikes"- attacks based on patterns of suspicious activity by a group of men, rather than "personality strikes" against particular militants—-were a hallmark of Obama's drone war. ${ }^{30}$ They decimated the ranks of lower-level combatants, killing somewhere between an estimated 1,659 and 2,683 suspected militants in Pakistan during Obama's tenure. ${ }^{31}$

In addition to signature strikes, Obama expanded targeting selection to include militant groups less directly threatening to the U.S. homeland compared to al-Qaida. More than a third of the Bush administration's strikes targeted al-Qaida; under Obama, that number stood at only $9 \%$. Under Obama, 47\% of drone strikes targeted the Taliban and the allied Haqqani network. ${ }^{32}$

An example of this shift in targeting came on October 11, 2012, when a drone strike killed a group of militants in Orakzai Agency in FATA believed to be loyal to Pakistani Taliban commander Hafiz Gul Bahadur. U.S. military officials had linked Bahadur's fighters to attacks on NATO troops in Afghanistan. ${ }^{33}$

This broadening of the target set coincided with a large surge of U.S. soldiers in Afghanistan. At the end of the Bush administration, there were more than 20,000 U.S. soldiers in Afghanistan. By mid-2010, there were 90,000..$^{34}$ Many of the drone strikes under Obama in the FATA occurred in the context of "force protection" of this larger contingent of U.S. soldiers.

The Obama administration's drone campaign in Pakistan peaked in 2010 but slowed considerably in 2011 as a result, in part, of deepening fissures in the U.S.-Pakistan relationship. The May 2011 raid by U.S. Navy SEALs on Bin Ladin's compound in Abbottabad in northern Pakistan, and a NATO airstrike six months later that inadvertently killed some two dozen Pakistani soldiers, greatly damaged relations between Washington and Islamabad, resulting in the closure of the CIA-controlled drone facility at Shamsi air base in Balochistan. ${ }^{35}$

At the same time, U.S. Ambassador to Pakistan Cameron Munter urged more judicious targeting of drone strikes as well as increased consultation with the Pakistanis. ${ }^{36}$ The drone strikes had long been unpopular among Pakistanis, who viewed them both as killing too many civilians and as violations of their national sovereignty. According to a Gallup poll from 2013, 70\% of Pakistanis surveyed opposed U.S. drone strikes in their country. ${ }^{37}$

A combination of the CIA drone base closure, State Department pressure to heed Pakistani sensitivities, greater scrutiny of the drone program by the American media and Congress, and a reduction of the U.S. military footprint in Afghanistan led to a 40\% drop in the number of strikes in 2011. There were 70 drone strikes in Pakistan in 2011, down from the record 122 in 2010 (see Figure 33.1).

Following this sharp drop, drone strikes in Pakistan continued to decline. The Obama administration conducted only three strikes in Pakistan in 2016. On May 21 of that year, the CIA conducted its final drone strike in Pakistan of Obama's presidency and the first outside of FATA, killing the Taliban's leader, Mullah Akhtar Mansour, in Balochistan. The administration then inaugurated a nine-month cessation of strikes in Pakistan, the longest such pause since Obama took office. ${ }^{39}$ It would remain the longest pause until President Donald Trump, who broke the pause but stopped conducting strikes following a strike on July 4, 2018, that initiated a more than two-year pause since the last known U.S. strike in Pakistan.

Even after the Obama administration halted drone strikes in Pakistan, the drone program continued in Yemen and Somalia, where two al-Qaida affiliates operated: AQAP and al-Shabaab. Umar Farouk Abdulmutallab, a Nigerian-born graduate student attending University College London, sought out the American cleric Anwar al-Awlaqi in Yemen. Al-Awlaqi, a leader of AQAP, directed Abdulmutallab to blow up an American passenger plane over U.S. soil. ${ }^{40}$ Deploying a hard-to-detect bomb secreted in his underwear, 


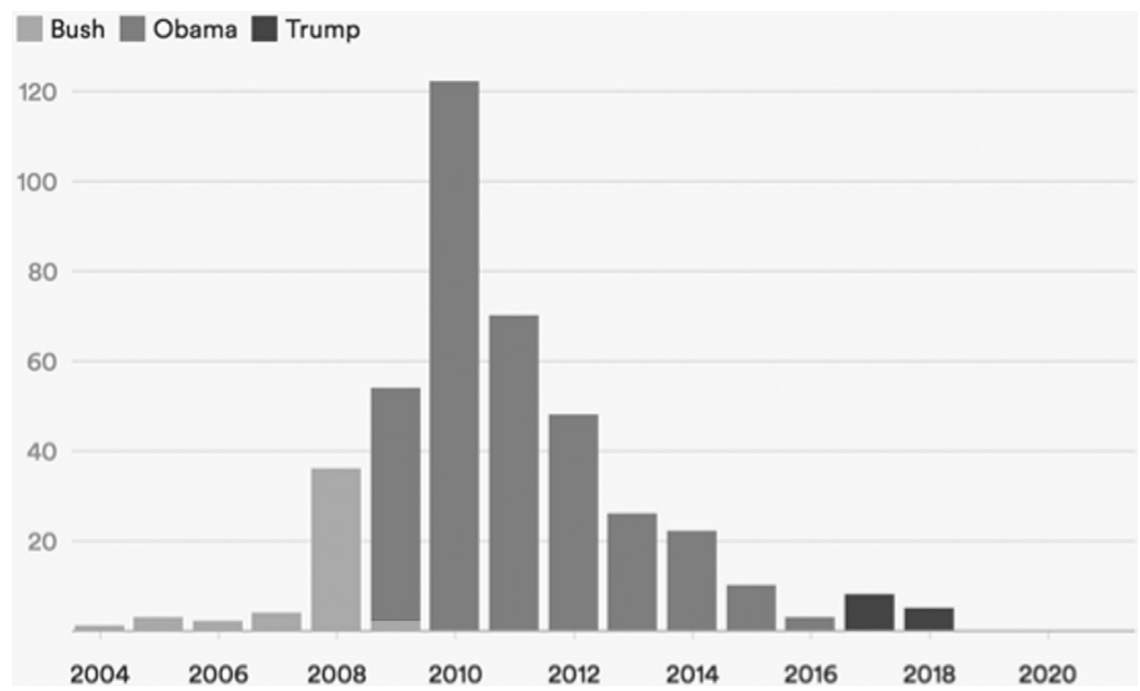

Figure 33.1 U.S. air and drone strikes in Pakistan, 2004-2020. ${ }^{38}$

Source: The data in this figure is drawn from research conducted by the authors and New America.

Abdulmutallab attempted to blow up Northwest Airlines Flight 253 as it flew over Detroit on Christmas Day 2009. The bomb did not detonate properly, saving the lives of the passengers and crew.

Obama first entered office not wanting terrorism to be a defining issue of his presidency, as it had been for his predecessor. Just as for President Bush, however, combating terrorist groups would become the dominant foreign policy issue for much of Obama's term. One of Obama's major campaign pledges was to end American involvement in both Iraq and Afghanistan, so he was not prepared to open a new war in the Arabian Peninsula. Obama explained his position: "We can't do in Yemen what we did in Afghanistan. We shouldn't have to spend tens of billions of dollars in Yemen because one scared kid from Nigeria was recruited to do something bad." ${ }^{41}$

While Obama did not want to launch a conventional war in Yemen after the Christmas Day incident, he still moved to take military action. The Bush administration had conducted only one drone strike in Yemen, while under the Obama administration, there were 185 strikes, ${ }^{42}$ resulting in an estimated 1,094 to 1,394 deaths. ${ }^{43}$ In Yemen, 56 drone and airstrikes took place in 2012, marking the first time that the number of drone strikes in Yemen and Pakistan had reached comparable levels. ${ }^{44}$

A controversial component of Obama's drone program was the use of so-called signature strikes, which he authorized for Pakistan's tribal regions and Yemen. ${ }^{45}$ Such strikes did not target militants identified as individuals but rather people deemed lawful targets for military action because they had displayed the behaviors of suspected militants. Stricter rules governed signature strikes in Yemen compared to Pakistan, and they were given a different name: Terrorist Attack Disruption Strikes. ${ }^{46}$

In addition to signature strikes, the Obama administration continued to target high-level leaders. U.S. national security officials began to portray the American-born AQAP leader Anwar al-Awlaqi as more threatening than even Bin Ladin. It was al-Awlaqi who was orchestrating al-Qaida's serious plots against American commercial jets.

Yet how could the U.S. intelligence community find someone hiding in a remote part of Yemen? Even if al-Awlaqi could be found, the administration could not send Federal Bureau of Investigation agents to arrest him. With only a few dozen U.S. Special Operations Forces in all of Yemen, mounting a ground operation had no guarantee of success. That left the drone option. 
Senior White House officials began debating whether they should target al-Awlaqi for death. Not since the Civil War had a president and his advisors seriously contemplated authorizing such a killing of an American citizen. The president and a small team of senior national security officials, including Attorney General Eric Holder, were in the unusual position of acting as al-Awlaqi's jury, judges, and de facto executioners. Just days after the Christmas Day plot, President Obama, the former constitutional law professor, gave his verbal approval to target al-Awlaqi for death. ${ }^{47}$

While the president had agonized over some of the decisions to target militants for death, the decision to kill al-Awlaqi was an "easy one." 48 In the president's mind, the weight of the evidence that al-Awlaqi was constantly plotting new ways to kill Americans was sufficient to order his death.

In July 2010, two lawyers at the Justice Department, David Barron and Marty Lederman, wrote a secret memo that established the legal rationale for why it was lawful under certain, specific circumstances for the president to authorize the killing of an American citizen. Merely being an American citizen, the memo argued, did not make one immune from being targeted. As an operational leader of al-Qaida actively working to kill Americans, al-Awlaqi posed an "imminent" threat of violent attack against the United States. Moreover, he was hiding in a remote area of Yemen where capture was simply not feasible. The Justice Department lawyers opined that if a drone operation were eventually used to kill al-Awlaqi, it would have to be conducted in such a manner that it comported with the "laws of war," such as avoiding civilian casualties. ${ }^{49}$

A confidential Justice Department "white paper" written around the same time introduced a broader concept of "imminence" than had previously been in use. An imminent threat no longer required the "United States to have clear evidence that a specific attack on U.S. persons and interests will take place in the immediate future." Instead, the memo argued that an "informed, high-level" U.S. official could lawfully target an American who had been "recently" involved in "activities" posing a threat of an attack on the United States and where there was "no evidence suggesting that he has renounced or abandoned such activities." ${ }^{50}$ In other words, an American could be targeted for death not only in the case where he was planning an imminent attack on the United States but if he had already been involved in such a plan and there was not a good reason to believe he would not try again.

In January 2011, demonstrations broke out in Yemen to protest against poor economic conditions and the regime of Yemeni President Ali Abdullah Saleh. This coincided with the Arab Spring revolts in other countries across North Africa and the Arabian Peninsula. AQAP made territorial gains amid the chaos, and the United States responded by substantially escalating drone strikes.

The U.S. government killed al-Awlaqi in a drone strike on September 30, 2011. ${ }^{51}$ It marked the first known case of the U.S. government targeting and killing a U.S. citizen since the Civil War. Samir Khan, another American jihadi, died alongside al-Awlaqi. Although Khan was not the target of the strike, he had risen to prominence as the editor of al-Qaida's Inspire magazine. Two weeks later, al-Awlaqi's American son, 16-year-old Abdulrahman al-Awlaqi, was killed during a strike that reportedly targeted an Egyptian al-Qaida leader, Ibrahim al-Banna. ${ }^{52}$

Drone strikes in Yemen continued to increase, peaking in 2012, but slowly began to drop through 2014 (see Figure 33.2). The decline would not last. In September 2014, Houthi rebels took the Yemeni capital, Sanaa, and AQAP exploited the discord, making a push for greater territory. The United States began to re-escalate its drone war due to AQAP's advances, including the group's seizure of the port city of Mukalla in April 2015..$^{54}$

Using the most conservative estimates, counterterrorism operations in Pakistan and Yemen authorized by the Obama administration killed more than 3,000 people. Using the most liberal estimates, the total number of people killed reached nearly $4,500 .{ }^{55}$ Put another way, using the most conservative estimates, the death toll from drone strikes under the Obama administration amounts to almost four times the number of prisoners (almost 800) placed at the Guantanamo Bay prison camp by the Bush administration. Obama told some of his aides drily: "Turns out I'm really good at killing people. Didn't know that was going to be a strong suit of mine." 56 


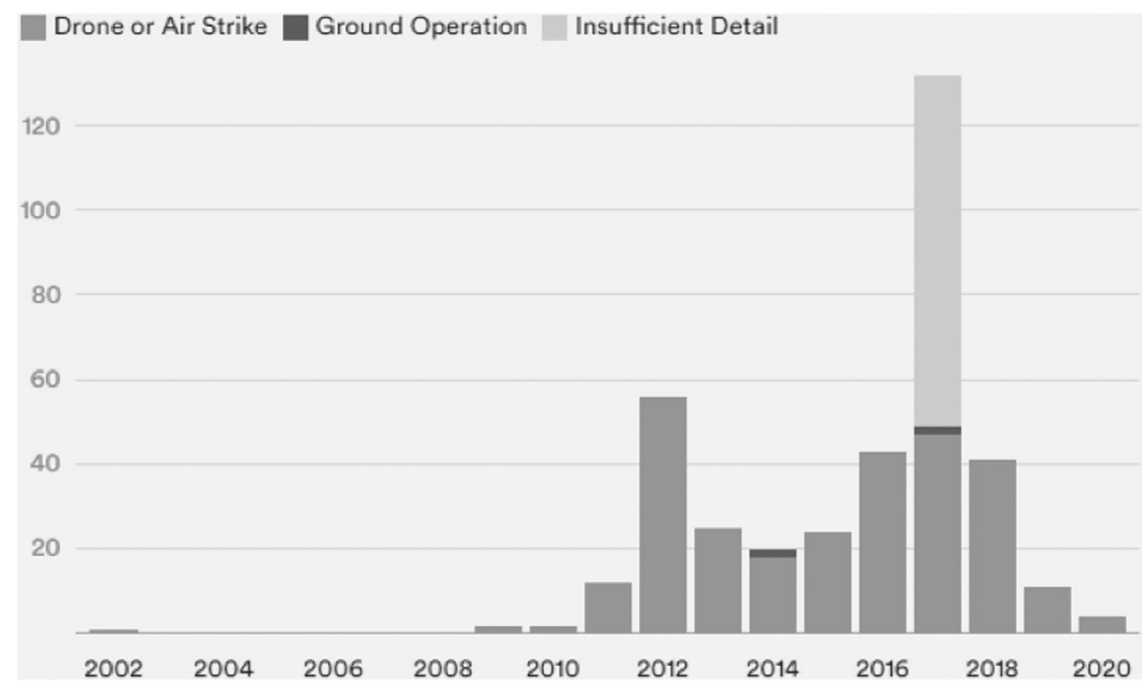

Figure 33.2 U.S. strikes in Yemen by type of strike, 2002-2020.53

Source: The data in this figure is drawn from research conducted by the authors and New America; data for 2020 is through December 1, 2020.

\section{Drone warfare under President Donald Trump}

In March 2017, President Donald Trump approved a Pentagon request to designate parts of three unnamed Yemeni provinces as "areas of active hostilities." The term has no clear, legal definition but authorizes the military to operate as it does in conventional war zones with broad authority to take action against terrorist targets at its own discretion. ${ }^{57}$

In the same month, Trump also granted the Pentagon's request to designate the entirety of Somalia as an "area of active hostilities" for six months. ${ }^{58}$ Marine Corps General Thomas Waldhauser, commander of U.S. Africa Command, confirmed in a press briefing:

We've been given authority to assist [African Union Mission in Somalia] forces that are on missions where, if they cannot take care of the situation on their own, then we are authorized to assist them there. We are also authorized to develop targets on our own and take appropriate action. ${ }^{59}$

Waldhauser also said that, despite the expanded rules of engagement, he was going to stick to the "near certainty" standard of no civilian casualties.

The Trump administration dramatically escalated the number of counterterrorism operations in Yemen in 2017 before substantially reducing the pace of strikes. The Trump administration conducted a total of 188 drone strikes, airstrikes, and ground operations in Yemen as of December 1, 2020. While strikes in Pakistan slowed, strikes in Somalia escalated significantly. The CIA conducted 13 drone strikes in Pakistan during the Trump administration, restarting the drone campaign in the country after a cessation of nine months under Obama.

The Trump administration again paused the campaign in Pakistan, however, and there has not been a U.S. strike in more than two years in the country. As of December 1, 2020, the Trump administration has conducted 193 airstrikes and ground operations in Somalia, the highest pace since the start of U.S. counterterrorism operations in Somalia in 2003 (see Figure 33.3). 


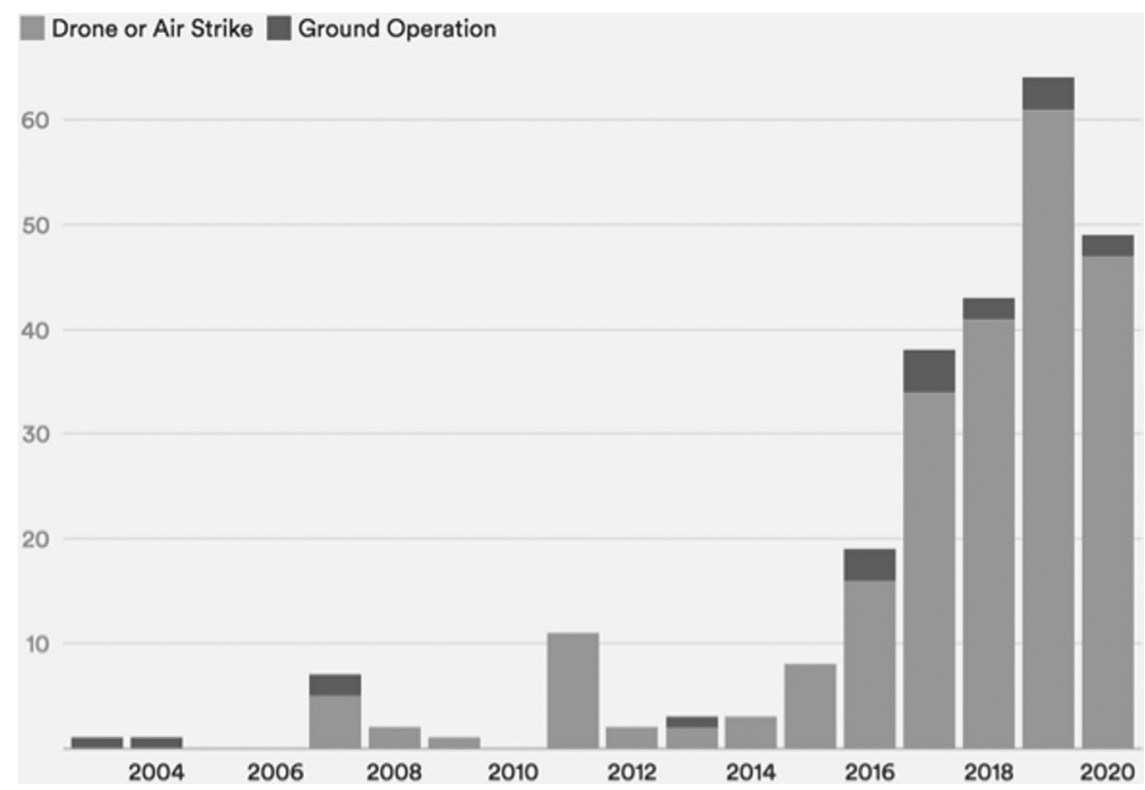

Figure 33.3 U.S. strikes in Somalia by type of strike, 2003-2020. ${ }^{60}$

Source: The data in this figure is drawn from research conducted by the authors and New America; data for 2020 is through December 1, 2020.

\section{Are CIA drone strikes effective at disrupting terrorist groups?}

U.S. drone strikes in Pakistan killed many top al-Qaida and Taliban leaders. Between 2004 and November 17, 2020, the drone campaign in Pakistan killed 95 militant leaders, according to New America data. It was so effective that before he was killed in the 2011 Navy SEAL raid, Bin Ladin considered moving al-Qaida's key figures out of Pakistan. ${ }^{61}$

In a lengthy October 2010 memo recovered from his Abbottabad compound after the raid, Bin Ladin wrote about the devastation that drones were inflicting on his organization and advised that his men leave the FATA region, where the drone strikes were overwhelmingly concentrated, and head to a remote part of Afghanistan. He also suggested that his son Hamza decamp from Pakistan's tribal regions for the wealthy Persian Gulf kingdom of Qatar. ${ }^{62}$

An account provided by David Rohde, a New York Times reporter who was held captive by the Haqqani network for months in 2009, provides additional evidence of the drone strikes' impact on Pakistan-based militants. In an essay reflecting on his captivity, Rohde said that his Taliban captors "feared drone strikes" and often tortured and executed villagers in Waziristan, an area of FATA, whom they suspected of secretly carrying global positioning system devices or otherwise providing guidance for U.S. drone strikes. ${ }^{63}$

The CIA drone attacks in Pakistan have undoubtedly degraded al-Qaida's core and hindered some of the Taliban's operations, killing many hundreds of each group's low-level fighters and many of their top commanders. After Abu Yahya al-Libi, the deputy leader of al-Qaida, was killed in a CIA drone strike in Pakistan's tribal region in 2012, senior U.S. counterterrorism officials concluded that only one leader of any consequence in al-Qaida's core group in the Afghanistan-Pakistan region remained: Ayman al-Zawahiri, the Egyptian surgeon who became the head of al-Qaida following Bin Ladin's death in $2011 .^{64}$

In April 2015, al-Qaida confirmed in an audio message that CIA drone strikes killed two of its leaders, Ustad Ahmad Farooq and Qari Abdullah Mansur, three months earlier in North Waziristan, near the 
Afghan-Pakistani border. ${ }^{65}$ Farooq, whose real name was Raja Mohammad Suleman, acted as the group's liaison to the Pakistani Taliban, and he was the deputy commander of al-Qaida's nascent South Asia branch. Mansur, whose real name was Qari Ubaidullah, oversaw suicide missions against U.S. and NATO troops in Afghanistan. ${ }^{66}$ The deaths of these two Pakistani al-Qaida leaders underlined the continuing decimation of the group's leadership in South Asia.

A 2015 RAND study, “The Impact of U.S. Drone Strikes on Terrorism in Pakistan,” used a statistical analysis based on New America's data and other datasets by non-governmental organizations to conclude that drone strikes reduced the threat posed by targeted groups in Pakistan through two mechanisms- the disruption of their operations and leadership decapitation. ${ }^{67}$

\section{Drone warfare and civilian casualties}

The U.S. drone campaign became increasingly controversial as it ramped up under the Obama administration. Human rights activists claimed that the attacks killed a substantial number of civilians, while Obama's top counterterrorism advisor, John Brennan, made the improbable claim in 2011 that there were no civilian casualties for nearly a year as a result of the strikes. ${ }^{68}$

How many civilians have actually been killed by drone strikes? This question is complicated by the fact that it is not always possible to differentiate precisely between militant and civilian casualties in Pakistan; the militants live among the population and do not wear uniforms, and they have the incentive to claim that all casualties are civilian, while government sources tend to claim the opposite. This can lead to conflicting media reports about whether the victims were militants or civilians, and in those unclear cases, New America added a separate category to its dataset of drone casualties: "Unknowns." Over the course of the drone war in Pakistan, an estimated 211 to 328 deaths are categorized as "unknowns." 99

By averaging the high and low casualty estimates of militant and non-militant deaths published in a wide range of reliable media outlets, New America estimates that the civilian death rate in U.S. drone strikes in Pakistan has declined dramatically since $2006 .^{70}$

Over the life of the CIA drone program in Pakistan, the estimated civilian death rate is $9 \%$, or between 245 and 303 individuals out of an estimated 2,366 to 3,700 total deaths. This civilian death rate average was $27 \%$ under Bush, while it was $6 \%$ under Obama. As of December 1, 2020, under Trump, it was approximately $4 \%$.

The civilian fatality rate from CIA drone strikes began to drop beginning in 2010 for a number of reasons. Three days after Obama took office, a drone strike killed at least five civilians on January 23, 2009, prompting the president to demand stricter targeting selection criteria from the CIA. Obama also wanted to personally authorize any strikes that the agency did not have "near certainty" would result in zero civilian casualties.

At the same time, technological innovations allowed the CIA to deploy much smaller munitions, and drones could circle over areas for longer periods, allowing them to target specific individuals with more precision and wait for an opportunity when no civilians were present. ${ }^{71}$ Figure 33.4 shows the annual number of fatalities from drone strikes in Pakistan, Yemen, Somalia, and Libya.

The drone program also came under increasing Congressional oversight. Since early 2010, members of the House Permanent Select Committee on Intelligence and the Senate Select Committee on Intelligence have held monthly meetings at CIA headquarters to watch video recordings of specific drone strikes, as well as to review the intelligence upon which CIA agents on the ground in Pakistan based their target selection. ${ }^{73}$

Even Pakistani security officials acknowledged during background interviews with the Washington Post in 2010 that better technology, a deeper network of on-the-ground informants, and better coordination between U.S. and Pakistani intelligence officials had all contributed to a significant drop in civilian deaths in drone strikes. ${ }^{74}$ In March 2011, Pakistani Major General Ghayur Mehmood acknowledged that 


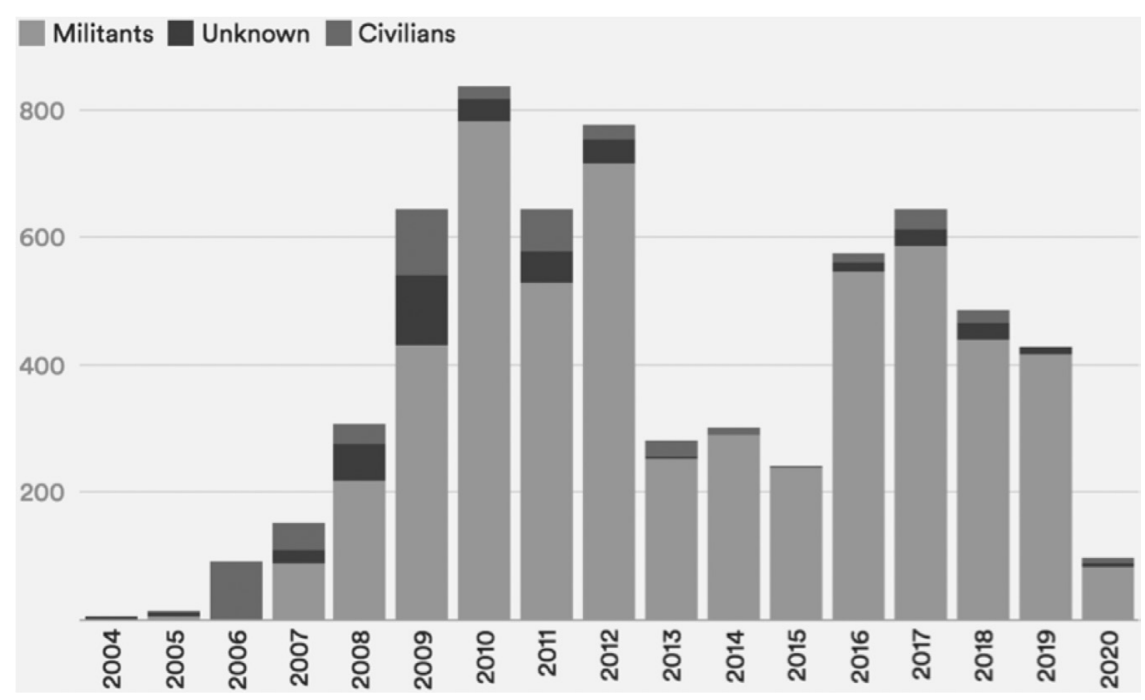

Figure 33.4 Deaths from drone strikes in Pakistan, Yemen, Somalia, and Libya, 2004-2020. ${ }^{72}$

Source: The data in this figure is drawn from research conducted by the authors and New America. This graphic likely undercounts the number of deaths in Yemen in 2017, due to gaps in CENTCOM data on strike date and location. Data for 2020 is through December 1, 2020.

U.S. drone strikes were accurate in terms of targeting. "The number of innocent people being killed is relatively low," Mehmood said, and "most of the targets are hard-core militants." It was the first such public acknowledgment by a senior Pakistani military officer. ${ }^{75}$

Despite improvements in precision, U.S. drone strikes in Pakistan's tribal regions are a continued point of tension contributing to the fracture of U.S.-Pakistan relations. On June 15, 2017, after a drone strike killed Abubakar Haqqani, a commander of the Haqqani network, Pakistan Army Chief General Qamar Javed Bajwa called U.S. strikes "counterproductive" and "against [the] spirit of . . ongoing cooperation and intelligence sharing being diligently undertaken by Pakistan."76

The widespread perception in Pakistan that drones kill too many civilians has persisted. According to a 2014 Pew poll, two-thirds of Pakistanis believe this to be the case. ${ }^{77}$ A Pew poll conducted two years earlier found that just $17 \%$ of Pakistanis supported the U.S. drone campaign to combat militants in their country. ${ }^{78}$

The drone attacks in Pakistan have undoubtedly hindered some operations of al-Qaida and the Taliban and have killed a significant number of their top commanders and their lower-level fighters. But they may also be fueling terrorism. Faisal Shahzad, an American citizen of Pakistani descent trained by the Pakistani Taliban, tried to detonate a car bomb in Times Square on May 1, 2010. The plot failed, but Shahzad subsequently claimed that the drone program had stoked his anger against the United States. ${ }^{79}$

Since 2012, Pakistani officials have rarely based their criticism of U.S. drone strikes on the incidence of civilian casualties but instead have pointed, quite reasonably, to another objection: the violation of Pakistan's national sovereignty. In April 2012, the Pakistani Parliament voted to end any authorization for the program, a vote the U.S. government has so far ignored. ${ }^{80}$ This may be because, despite their public protests, some senior Pakistani officials privately supported the drone strikes.

Confirmation of official Pakistani support for the strikes came in April 2013, when former Pakistani President Pervez Musharraf acknowledged to the media that his government had secretly signed off on some U.S. drone strikes under the Bush administration. This was the first public admission by a senior Pakistani official of such a deal. Musharraf claimed that Pakistan's government allowed strikes "only on a few occasions, when a target was absolutely isolated and no chance of collateral damage." ${ }^{81}$ 
Meanwhile, in the United States, the drone program has enjoyed significant support. In a 2015 Pew poll, 58\% of Americans said they approved of lethal drone attacks in countries such as Pakistan, Yemen, and Somalia. ${ }^{82}$ This is not surprising because the human, financial, and political costs of the drone program for Americans are very low. Drone pilots and their support staff are not on the field of battle, and a drone costs a tiny fraction of the price of a fighter jet or a bomber. ${ }^{83}$

\section{The CIA drone program comes out of the shadows}

The U.S. government has somewhat pulled back the curtain on the drone program, which was shrouded in secrecy for more than a decade. The United States has acknowledged the program and has increased transparency regarding the rules that govern counterterrorism operations. President Obama made his first public comments about the covert drone program on January 30, 2012, when he told participants of a Google+ Hangout that the United States conducts only "very precise, precision strikes against al-Qaida and their affiliates, and we're very careful in terms of how it's been applied." ${ }^{84}$

Obama explained the rationale for the drone program in a 2013 speech at National Defense University, saying: "In some of these places — such as parts of Somalia and Yemen - the state has only the most tenuous reach into the territory. In other cases, the state lacks the capacity or will to take action," implicitly referring to Pakistan's unwillingness or inability to capture or kill militants in FATA. Obama also pointed to the degradation of al-Qaida core's capabilities since $9 / 11$ as evidence of the program's efficacy.

During the same speech, Obama announced the codification of his Presidential Policy Guidance, which established a framework and standards for the targeted killing of combatants. ${ }^{85}$ The American Civil Liberties Union petitioned for the document's release in 2013, but was denied on the basis of "presidential communications" privilege. ${ }^{86}$ After a judicial review raised questions regarding the privilege, the Obama administration released a redacted version of the document in August 2016.

Obama's Presidential Policy Guidance states, "Lethal action should be taken in an effort to prevent terrorist attacks against U.S. persons only when capture of an individual is not feasible and no other reasonable alternatives exist to effectively address the threat." The 18-page document also states that lethal action can be taken only against lawful targets who pose a "continuing, imminent threat," a determination that is made by the "nominating department's or agency's counsel" and is subject to legal review. There must also be a "near certainty" that the action will not kill civilians, termed "non-combatants" in the Presidential Policy Guidance.

The Presidential Policy Guidance release followed a separate drone program disclosure just one month prior. In July 2016, the White House released Obama's executive order on "United States Policy on Preand Post-Strike Measures to Address Civilian Casualties in U.S. Operations Involving the Use of Force," which outlined best practices to avoid civilian casualties. ${ }^{87}$ The U.S. government "routinely imposes certain heightened policy standards that are more protective" than required by the law of armed conflict, according to the document. ${ }^{88}$

In accordance with these standards, the order says the agencies involved in lethal activities must accept responsibility for civilian casualties and "offer condolences, including ex gratia payments" to injured civilians or the families of those killed. ${ }^{89}$ Obama's directive also required an unclassified summary of strike information, including civilian casualties, no later than May 1,2017, and by May 1 of each subsequent year. ${ }^{90}$

A supplemental fact sheet accompanying the executive order included a release of aggregate data on lethal strikes undertaken against terrorist targets by the Obama administration..$^{91}$ The Office of the Director of National Intelligence estimated the civilian death toll from the covert drone program to be between 64 and 116 from January 20, 2009, to December 31, 2015, which was below the estimates of independent organizations such as New America. ${ }^{92}$ Across Pakistan and Yemen, drone strikes and other counterterrorism 
operations killed an estimated 218 to 263 civilians during this period, according to New America data. New America recorded no civilian casualties in Somalia during this period.

In 2013, Obama signaled plans to transfer the drone program in Yemen to the Pentagon. This resulted in a years-long push by the White House to have the Department of Defense run the program in the interests of transparency and greater oversight. ${ }^{93}$ This move, however, garnered bipartisan pushback in Congress, including leaders on the House and Senate Intelligence Committees, who said the CIA had a more robust intelligence infrastructure for conducting precise strikes. ${ }^{94}$ In 2016, the U.S. military began reporting strikes in Yemen and Somalia in press releases, indicating that the program had, in fact, been transferred to the Pentagon. ${ }^{95}$

As of November 2020, much of the U.S. drone program has been transferred from the CIA to the Department of Defense, although there were efforts by the Trump administration to expand the CIA's authority over the program. ${ }^{96}$ The U.S. military has long operated armed drones throughout the wars in Afghanistan and Iraq and the conflict in Syria. ${ }^{97}$ The CIA has always overseen the U.S. drone program in Pakistan, and both the CIA and Joint Special Operations Command have conducted drone strikes in Yemen.

In 2017, the Air Force retired the MQ-1 Predator drone, which the United States had used to conduct its first drone strikes in the wake of $9 / 11 .{ }^{98}$ The Predator's replacement, the similarly designed but much larger MQ-9 Reaper, is outfitted with a two-ton payload, a significant increase from the maximum 200pound payload of missiles and bombs that the Predator could carry at a given time. It is the reconnaissance ability of drones that makes the Reaper's option of carrying two tons of missiles and bombs a more effective counterterrorism weapon than, for instance, an F-16 that carries a similar payload but cannot surveil potential targets for hours.

The U.S. drone program has influenced global drone production and drone use in combat. On September 7, 2015, Pakistan conducted a drone strike-using an indigenously built drone-in the Shawal Valley in North Waziristan, a tribal region bordering Afghanistan. ${ }^{99}$ Three "high-profile" terrorists were killed, according to a Pakistan Army spokesman. ${ }^{100}$ While the U.S. sells armed drones only to select allied nations, ${ }^{101}$ China is a growing drone exporter and has filled gaps in the market with its more liberal export policy. ${ }^{102}$

In December 2015, Iraqi armed forces released video footage of a Chinese Cai Hong-4 blasting an Islamic State position in Ramadi. ${ }^{103}$ A photo appeared on an online blog in January 2015 of a crashed Chinese-made drone in Nigeria. ${ }^{104}$ On February 3, 2016, Nigeria reported the military's first use of an armed drone, striking at the militant group Boko Haram. ${ }^{105}$ Nigeria used the Chinese Cai Hong-3 to conduct the strike. ${ }^{106}$

\section{Conclusion}

Armed drones raise a number of moral and political questions. In Pakistan, the CIA drone campaign is deeply unpopular because many Pakistanis ask themselves: What gives the United States the right to invade the sovereign airspace of our nation and sometimes kill our civilians, even in the service of the laudable goal of killing al-Qaida and Taliban militants?

That said, the ability of drones to linger over and assess a target for many hours, and then act against that target immediately, is a capability that can quite dramatically lower the civilian casualty rates typical of earlier eras of warfare. A drone can provide a heightened level of distinction between combatants and non-combatants because it can loiter at length over a target. In that sense, there is a case to be made that armed drones presage a more ethical form of warfare that kills fewer civilians.

It is not an accident that the rise of drone warfare has coincided with America's unconventional war against al-Qaida and its allies. In conventional wars, armies wearing uniforms attack each other. Yet with 
the type of drone warfare that the United States has conducted since 9/11 outside of conventional war zones in countries such as Pakistan and Yemen, drone strikes are not directed at individuals because of their status as a uniformed member of another military force but rather because of the individual's suspected connection to al-Qaida or an allied militant group.

In many ways, the use of armed drones is akin to the use of cyber warfare. Both tactics greatly reduce or eliminate the deaths that would result from a conventional armed conflict. Whoever launches a drone attack or a cyberattack pays no costs of the kind that would typically take place on a conventional battlefield. An adversary cannot shoot down a drone pilot or kill a computer technician launching a cyberattack thousands of miles from the intended target. For this reason, an argument can be made that drones and cyber capabilities can make conflict more likely, as the barriers to engage in either drone warfare or cyber conflict are relatively low.

Drones have also consolidated military and intelligence roles such as reconnaissance, data collection, targeting, communications, and killing into a single platform, making drones the counterterrorism weapon of choice for three very different U.S. presidents. The fact that Presidents Bush, Obama, and Trump all embraced armed drones as a key counterterrorism tool underlines that this tactic is now an embedded feature of U.S. national security policy.

\section{Notes}

1 Thanks to David Sterman and Albert Ford for their input on this chapter. Also, thanks to Joshua Geltzer, Luke Hartig, and Daniel Rothenberg for their feedback. Thanks to Ethan Walker and Brianna Kablack for their help with footnotes, data updates, and appendices.

2 Thomas Gibbons-Neff, "U.S. Airstrike Kills More Than 150 at Somalia Terrorist Camp, Military Says," Washington Post, March 7, 2016, www.washingtonpost.com/news/checkpoint/wp/2016/03/07/u-s-drone-strikekills-more-than-150-in-somalia/.

3 Ibid.; Helene Cooper, "U.S. Strikes in Somalia Kill 150 Shabaab Fighters," New York Times, March 7, 2016, www. nytimes.com/2016/03/08/world/africa/us-airstrikes-somalia.html.

4 Chris Woods, "The Story of America's Very First Drone Strike," The Atlantic, May 30, 2015, www.theatlantic. com/international/archive/2015/05/america-first-drone-strike-afghanistan/394463/; James Cavallaro, Stephan Sonnenberg, and Sarah Knuckey, Living Under Drones: Death, Injury, and Trauma to Civilians From US Drone Practices in Pakistan (Stanford: International Human Rights and Conflict Resolution Clinic, 2012), 11-12.

5 In this chapter, the term "counterterrorism operations" includes drone strikes and U.S. Special Operations Forces ground raids.

6 Barton Gellman and Ashkan Soltani, "NSA Surveillance Program Reaches 'Into the Past' to Retrieve, Replay Phone Calls," Washington Post, March 18, 2014, www.washingtonpost.com/world/national-security/nsa-surveillance-program-reaches-into-the-past-to-retrieve-replay-phone-calls/2014/03/18/226d2646-ade9-11e3-a49e76adc9210f19_story.html.

7 This passage draws from Daniel Rothenberg, "Drones and the Emergence of Data-Driven Warfare," in Drone Wars: Transforming Conflict, Law, and Policy, ed. Peter Bergen and Daniel Rothenberg (New York: Cambridge University Press, 2014), 441-462; Peter Bergen "Drones Will Fill the Sky," CNN, May 13, 2014, www.newamerica.org/ international-security/articles/drones-will-fill-the-sky/.

8 Spencer Ackerman and Noah Shachtman, "Almost 1 in 3 U.S. Warplanes Is a Robot," Wired, January 9, 2012, www.wired.com/2012/01/drone-report/.

9 Since 2011, Libya has been both a conventional war zone authorized by the United Nations and a nontraditional battlefield.

10 Authorization for Use of Military Force, Pub. L. No. 107-40 \1, 115 Stat. 225 (2001), www.congress.gov/107/ plaws/publ40/PLAW-107publ40.pdf.

11 Ibid.

12 Ibid.

13 Office of the Historian, Foreign Relations of the United States, 1945-1950, Emergence of the Intelligence Establishment: National Security Council Directive on Office of Special Projects (Washington, DC: U.S. Department of State, 1948).

14 Fred Kaplan, “The First Drone Strike," Slate, September 14, 2016, https://slate.com/news-and-politics/2016/09/ahistory-of-the-armed-drone.html. 
15 Peter Bergen, The Longest War: The Enduring Conflict Between America and Al-Qaeda (New York: Simon and Schuster, 2011), 45.

16 Ibid.

17 Woods, "The Story of America's Very First Drone Strike."

18 "Operation Enduring Freedom Fast Facts," CNN, October 5, 2016, www.cnn.com/2013/10/28/world/opera tion-enduring-freedom-fast-facts/index.html.

19 Peter Bergen, Manhunt: From 9/11 to Abbottabad - The Ten-Year Search for Osama Bin Laden (London: The Bodley Head, 2012), 39.

20 Ibid.

21 Mark Mazzetti, “A Secret Deal on Drones, Signed in Blood," New York Times, April 6, 2013, www.nytimes. com/2013/04/07/world/asia/origins-of-cias-not-so-secret-drone-war-in-pakistan.html.

22 Peter Bergen and Katherine Tiedemann, “The Drone War," The New Republic, June 3, 2009, https://newrepublic. com/article/61767/the-drone-war.

23 Ibid.

24 “America's Counterterrorism Wars-Drone Strikes: Pakistan," New America, 2017, www.newamerica.org/ in-depth/americas-counterterrorism-wars/pakistan/.

25 Bergen and Tiedemann, "The Drone War."

26 Peter Bergen and Jennifer Rowland, "Drone Wars," The Washington Quarterly 36, no. 3 (2013): 7-26.

27 "America’s Counterterrorism Wars-Drone Strikes: Pakistan."

28 Ibid.

29 Ibid.

30 Eric Schmitt, "U.S. to Step Up Drone Strikes in Yemen," New York Times, April 25, 2012, www.nytimes. com/2012/04/26/world/middleeast/us-to-step-up-drone-strikes-inside-yemen.html.

31 "America's Counterterrorism Wars-Drone Strikes: Pakistan."

32 These percentages are based on New America data.

33 Zahir Shah Sherazi, "US Drone Strikes in Orakzai Kill 16 Suspected Militants," Dawn, October 11, 2012, www. dawn.com/news/755894/us-drone-attack-kills-five-suspected-militants-in-orakzai-agency.

34 Helene Cooper and Eric Schmitt, "U.S. Officials Debate Speeding Afghan Pullout," New York Times, March 13, 2012, www.nytimes.com/2012/03/13/world/asia/us-officials-debate-speeding-up-afghan-pullout.html.

35 Salman Masood, “C.I.A. Leaves Base in Pakistan Used for Drone Strikes,” New York Times, December 11, 2011, www.nytimes.com/2011/12/12/world/asia/cia-leaves-pakistan-base-used-for-drone-strikes.html.

36 Adam Entous, Siobhan Gorman, and Julian E. Barnes, "U.S. Tightens Drone Rules," Wall Street Journal, November 4, 2011, www.wsj.com/articles/SB10001424052970204621904577013982672973836.

37 “Public Opinion about Drone Strikes in Pakistan," Gallup Pakistan, December 7, 2013, https://gallup.com.pk/ bb_old_site/pollsshow.php?id=2013-12-07.

38 The data in this figure is drawn from research conducted by the authors and New America.

39 Peter Bergen and David Sterman, "Will President Trump Restart the Drone War in Pakistan?” CNN, January 21, 2017, www.cnn.com/2017/01/21/opinions/trump-drone-war-in-pakistan-bergen-sterman/index.html.

40 Scott Shane, "Inside Al Qaeda's Plot to Blow Up an American Airliner," New York Times, February 22, 2017, www. nytimes.com/2017/02/22/us/politics/anwar-awlaki-underwear-bomber-abdulmutallab.html.

41 Peter Bergen, United States of Jihad: Investigating America's Homegrown Terrorists (New York: Crown Publishers, 2016), 203.

42 A small number of the 185 strikes conducted in Yemen under Obama were cruise missile strikes or ground operations by Special Operations Forces.

43 “America's Counterterrorism Wars—Drone Strikes: Yemen," New America, 2017, www.newamerica.org/in-depth/ americas-counterterrorism-wars/us-targeted-killing-program-yemen/.

44 Peter Bergen, “Obama's High-Stakes Drone War in Yemen," CNN, April 21, 2014, www.cnn.com/2014/04/21/ opinion/bergen-yemen-obama-drone-war/index.html.

45 Jo Becker and Scott Shane, "Secret 'Kill List' Proves a Test of Obama's Principles and Will," New York Times, May 29, 2012, www.nytimes.com/2012/05/29/world/obamas-leadership-in-war-on-al-qaeda.html.

46 Ibid.

47 Peter Bergen, "The American Who Inspires Terror From Paris to the U.S.," CNN, January 12, 2015, www.cnn. com/2015/01/11/opinion/bergen-american-terrorism-leader-paris-attack/index.html.

48 Ibid.

49 Office of the Assistant Attorney General, "Memorandum for the Attorney General Re: Applicability of Federal Criminal Laws and the Constitution to Contemplated Lethal Operations Against Shaykh Anwar al-Aulaqi" (official memorandum, Washington, DC: Department of Justice, 2010). 
50 Michael Isikoff, "Justice Department Memo Reveals Legal Case for Drone Strikes on Americans," NBC News, February 5, 2013.

51 Mark Mazzetti, Eric Schmitt and Robert F. Worth, "Two-Year Manhunt Led to Killing of Awlaki in Yemen," New York Times, September 30, 2011, www.nytimes.com/2011/10/01/world/middleeast/anwar-al-awlaki-is-killed-inyemen.html.

52 Peter Finn and Greg Miller, "Anwar al-Awlaki’s Family Speaks Out Against His, Son's Deaths," Washington Post, October 17, 2011, www.washingtonpost.com/world/national-security/anwar-al-awlakis-family-speaks-outagainst-his-sons-deaths/2011/10/17/gIQA8kFssL_story.html.

53 The data in this figure is drawn from research conducted by the authors and New America; data for 2020 is through December 1, 2020.

54 Saeed al-Batati and Kareem Fahim, "Affiliate of Al Qaeda Seizes Major Yemeni City, Driving Out the Military," New York Times, April 3, 2015, www.nytimes.com/2015/04/04/world/middleeast/al-qaeda-al-mukallayemen.html; "America's Counterterrorism Wars—Drone Strikes: Yemen."

55 Ibid.; "America's Counterterrorism Wars—Drone Strikes: Pakistan."

56 Bergen, "Drones Will Fill the Sky."

57 Charlie Savage and Eric Schmitt, "Trump Is Said to Be Working to Loosen Counterterrorism Rules," New York Times, March 12, 2017, www.nytimes.com/2017/03/12/us/politics/trump-loosen-counterterrorism-rules.html; Paul D. Shinkman, “'Areas of Active Hostilities': Trump's Troubling Increases to Obama's Wars,” U.S. News \& World Report, May 16, 2017, www.usnews.com/news/world/articles/2017-05-16/areas-of-active-hostilities-trumpstroubling-increases-to-obamas-wars.

58 Charlie Savage and Eric Schmitt, "Trump Eases Combat Rules in Somalia Intended to Protect Civilians," New York Times, March 30, 2017, www.nytimes.com/2017/03/30/world/africa/trump-is-said-to-ease-combat-rulesin-somalia-designed-to-protect-civilians.html.

59 "Transcript: Telephonic Press Briefing with AFRICOM, MNJTF, AMISOM Commanders on African Security," Global Sentinel, April 21, 2017, https://globalsentinelng.com/2017/04/21/transcript-telephonic-pressbriefing-africom-mnjtf-amisom-commanders-african-security/.

60 The data in this figure is drawn from research conducted by the authors and New America; data for 2020 is through December 1, 2020.

61 Peter Bergen, “A Gripping Glimpse into Bin Laden's Decline and Fall," CNN, March 12, 2015, www.cnn. com/2015/03/10/opinions/bergen-bin-laden-al-qaeda-decline-fall/index.html.

62 Usama bin Ladin, "Letter from UBL to 'Atiyatullah Al-Libi 2," SOCOM-2012-0000010, April 26, 2011, 8, https://ctc.usma.edu/wp-content/uploads/2013/10/Letter-from-UBL-to-Atiyatullah-Al-Libi-2-Translation.pdf; Usama Bin Ladin, "Letter from UBL to "Atiyatullah Al-Libi 3," SOCOM-2012-00000015, October 21, 2010, https://ctc.usma.edu/wp-content/uploads/2013/10/Letter-from-UBL-to-Atiyatullah-Al-Libi-3-Translation1.pdf.

63 David Rohde, "My Guards Absolutely Feared Drones: Reflection on Being Held Captive for Seven Months by the Taliban," in Drone Wars: Transforming Conflict, Law, and Policy, ed. Peter Bergen and Daniel Rothenberg (New York: Cambridge University Press, 2014), 9-11.

64 Declan Walsh and Eric Schmitt, "Drone Strike Killed No. 2 in Al Qaeda, U.S. Officials Say," New York Times, June 5, 2012. www.nytimes.com/2012/06/06/world/asia/qaeda-deputy-killed-in-drone-strike-in-pakistan. html.

65 Peter Bergen, “Al Qaeda's Bench of Leaders Dwindles," CNN, April 14, 2015, www.cnn.com/2015/04/14/opinions/al-qaeda-fading-peter-bergen/index.html.

66 Ibid.

67 Patrick Johnston and Anoop Sarbahi, "The Impact of US Drones Strikes on Terrorism in Pakistan," International Studies Quarterly 60, no. 2 (2016): 203-219.

68 Scott Shane, "C.I.A. Is Disputed on Civilian Toll in Drone Strikes," New York Times, August 11, 2011, www. nytimes.com/2011/08/12/world/asia/12drones.html.

69 "America's Counterterrorism Wars-Drone Strikes: Pakistan."

70 It has been reported that the Obama administration considered any military-age male in the strike target area a "militant." Our data, however, is not based on the official U.S. definition of a militant and does not rely on any official U.S. counting of the strikes. Rather, we record a militant only as someone identified in credible news reports as a militant or a "suspected militant." Credible news reports must come from certain respected media outlets. We judge a variety of sources to be credible in collecting information, including the Associated Press, Reuters, and Agence France-Presse; the New York Times, the Washington Post, the Los Angeles Times, and the Wall Street Journal; the British newspapers The Telegraph and The Guardian; the Pakistani news outlets The Express Tribune, Dawn, The Daily Times, Geo TV, and The News; and the BBC and CNN. The majority of these sources acquire information on CIA drone strikes in Pakistan from Pakistani intelligence, security, and local government officials, as well as local 
villagers. With such a range of sources, one can be reasonably sure that the data avoids the official U.S. government definition of a militant. If two or more media reports refer to those killed as militants, they are labeled as militants in our data. Similarly, if two or more media reports refer to those killed as civilians, they go under the civilian column. The murkiness of some reporting in the tribal regions of Pakistan and in Yemen led our researchers to designate another category for "unknown" casualties, which are assigned if different media reports on a single strike are so contradictory that researchers do not feel comfortable placing either label on those killed.

71 Becker and Shane, "Secret 'Kill List'."

72 The data in this figure is drawn from research conducted by the authors and New America. This graphic likely undercounts the number of deaths in Yemen in 2017 due to gaps in CENTCOM data on strike date and location. Data for 2020 is through December 1, 2020.

73 Bergen and Rowland, "Drone Wars."

74 Joby Warrick and Peter Finn, "Amid Outrage Over Civilian Deaths in Pakistan, CIA Turns to Smaller Missiles," Washington Post, April 26, 2010.

75 Peter Bergen and Jennifer Rowland, "Drones Decimating Taliban in Pakistan," CNN, July 3, 2012, www.cnn. com/2012/07/03/opinion/bergen-drones-taliban-pakistan/index.html.

76 “Bajwa Terms US Drone Strike Counterproductive," Dawn, June 15, 2017, www.dawn.com/news/1339621/ bajwa-terms-us-drone-strike-counterproductive.

77 “A Less Gloomy Mood in Pakistan,” Pew Research Center, August 27, 2014, www.pewresearch.org/ global/2014/08/27/a-less-gloomy-mood-in-pakistan/.

78 “Pakistani Public Opinion Ever More Critical of U.S.," Pew Research Center, June 27, 2012, www.pewresearch.org/ global/2012/06/27/pakistani-public-opinion-ever-more-critical-of-u-s/.

79 Lorraine Adams and Ayesha Nasir, "Inside the Mind of the Times Square Bomber," Guardian, September 18, 2010, www.theguardian.com/world/2010/sep/19/times-square-bomber.

80 Richard Leiby, "Pakistan Calls for End to U.S. Drone Attacks," Washington Post, April 12, 2012, www.washingtonpost.com/world/pakistan-calls-for-end-to-us-drone-attacks/2012/04/12/gIQAN1ZFDT_story.html.

81 Nic Robertson and Chris Botelho, "Ex-Pakistani President Musharraf Admits Secret Deal With U.S. on Drone Strikes," CNN, April 12, 2013, www.cnn.com/2013/04/11/world/asia/pakistan-musharraf-drones/index.html.

82 "Public Continues to Back U.S. Drone Attacks," Pew Research Center, May 28, 2015, www.pewresearch.org/ politics/2015/05/28/public-continues-to-back-u-s-drone-attacks/.

83 Bergen and Rowland, "Drone Wars."

84 Ibid.; Bergen and Rowland, "Drones Decimating Taliban."

85 “Obama's Speech on Drone Policy," New York Times, May 23, 2013, www.nytimes.com/2013/05/24/us/politics/ transcript-of-obamas-speech-on-drone-policy.html.

86 Karen DeYoung, "Newly Declassified Document Sheds Light on How President Approves Drone Strikes," Washington Post, August 6, 2016, www.washingtonpost.com/world/national-security/newly-declassified-documentsheds-light-on-how-president-approves-drone-strikes/2016/08/06/f424fe50-5be0-11e6-831d-0324760ca856_ story.html.

87 Office of the Press Secretary, Executive Order-United States Policy on Pre- and Post-Strike Measures to Address Civilian Casualties in the US Operations Involving Use of Force (Washington, DC: White House, 2016).

88 Ibid.

89 Ibid.

90 Ibid.

91 Ibid.

92 "Summary of Information Regarding U.S. Counterterrorism Strikes Outside Areas of Active Hostilities," Office of the Director of National Intelligence, July 1, 2016, www.dni.gov/index.php/newsroom/reports-publications/reportspublications-2016/item/1607-summary-of-information-regarding-u-s-counterterrorism-strikes-outside-areas-ofactive-hostilities.

93 Jack Goldsmith, "Questions About CIA v. DOD Drone Strikes," Lawfare (blog), May 13, 2014, www.lawfareblog. com/questions-about-cia-v-dod-drone-strikes.

94 Jim Acosta, "Obama to Make New Push to Shift Control of Drones from CIA to Pentagon," CNN, April 27, 2015, www.cnn.com/2015/04/27/politics/drones-cia-pentagon-white-house/index.html; Greg Miller, "Obama's New Drone Policy Leaves Room for CIA Role," Washington Post, May 25, 2013, www.washingtonpost.com/ world/national-security/obamas-new-drone-policy-has-cause-for-concern/2013/05/25/0daad8be-c480-11e2914f-a7aba60512a7_story.html.

95 "U.S. Central Command Announces Yemen Counterterrorism Strikes," U.S. Central Command, May 9, 2016, www.defense.gov/Explore/News/Article/Article/755391/us-central-command-announces-yemen-counter terrorism-strikes/; "U.S. Forces Conduct Defensive Fires in Somalia Against al-Shabaab Terrorists in May," U.S. 
Africa Command, June 17, 2016, www.africom.mil/pressrelease/28236/u-s-forces-conduct-defensive-fires-insomalia-against-al-shabaab-terrorists-in-may.

96 Eric Schmitt and Matthew Rosenberg, "C.I.A. Wants Authority to Conduct Drone Strikes in Afghanistan for the First Time," New York Times, September 15, 2017, www.nytimes.com/2017/09/15/us/politics/cia-drone-strikeauthority-afghanistan.html.

97 Dan Gettinger, Drone Operating in Syria and Iraq (Annandale-On-Hudson, NY: Center for the Study of the Drone, 2016).

98 Christian Clausen, "Air Force to Retire MQ-1 Predator Drone, Transition to MQ-9 Reaper," U.S. Department of Defense, February 27, 2017, www.defense.gov/Explore/News/Article/Article/1095612/air-force-to-retiremq-1-predator-drone-transition-to-mq-9-reaper/.

99 Mateen Haider, “Three Killed in Military's First Drone Strike in North Waziristan,” Dawn, September 7, 2015, www.dawn.com/news/1205455.

100 Ibid.

101 Missy Ryan, "Obama Administration to Allow Sales of Armed Drones to Allies," Washington Post, February 17, 2015, www.latimes.com/nation/la-na-drone-sales-20150217-story.html.

102 ValerieInsinna, “GeneralAtomics:ExportRestrictionsHelpChina GrowItsDrone Tech,” Defense News, August18,2017, www.defensenews.com/air/2017/08/18/general-atomics-export-restrictions-help-china-grow-its-drone-tech/.

103 Patrick Boehler and Gerry Doyle, "Use by Iraqi Military May Be a Boon for China-Made Drones," New York Times, December 17, 2015, www.nytimes.com/2015/12/18/business/international/china-drone-export-iraq.html.

104 Jeffrey Lin and P.W. Singer, "Did an Armed Chinese-Made Drone Just Crash in Nigeria?” Popular Science, January 28, 2015, www.popsci.com/did-armed-chinese-made-drone-just-crash-nigeria/.

105 Kelsey D. Atherton, "Watch Nigeria's First Confirmed Drone Strike-Against Boko Haram: Video Proof of a Long-Suspected Weapon,” Popular Science, February 3, 2016, www.popsci.com/watch-nigerias-first-confirmeddrone-strike/.

106 Ibid. 